\title{
Patterns and regulating mechanisms of soil nitrogen mineralization and temperature sensitivity in Chinese terrestrial ecosystems
}

\author{
Liu Yuan ${ }^{\mathrm{a}, \mathrm{b}}$, He Nianpeng ${ }^{\mathrm{a}, *}$, Wen Xuefa $^{\mathrm{a}}$, Yu Guirui ${ }^{\mathrm{a}}$, Gao Yang ${ }^{\mathrm{a}}$, Jia Yanlong ${ }^{\mathrm{a}}$ \\ ${ }^{a}$ Key Laboratory of Ecosystem Network Observation and Modeling, Institute of Geographic Sciences and Natural Resources Research, Chinese Academy of \\ Sciences, Beijing 100101, China \\ ${ }^{\mathrm{b}}$ University of Chinese Academy of Sciences, Beijing 100049, China
}

\section{A R T I C L E I N F O}

\section{Article history:}

Received 22 January 2015

Received in revised form 1 September 2015

Accepted 14 September 2015

Available online 25 September 2015

\section{Keywords:}

Decomposition

Latitude

Nitrogen

Temperature sensitivity

Soil organic matter

\begin{abstract}
A B S T R A C T
The mineralization (or decomposition) processes of soil organic matter(SOM), from organic to inorganic, play important roles in supplying most of nutrient for plant growth. Thus, understanding the spatial pattern and regulating mechanisms of soil nitrogen mineralization rate $\left(\mathrm{N}_{\min }\right)$ and its temperature sensitivity $\left(Q_{10}\right)$ is of great significance for evaluating ecosystem productivity and the supply of soil available nitrogen $(\mathrm{N})$. Here, data derived from 212 published papers in Chinese terrestrial ecosystems were used to explore the spatial pattern and regulating mechanisms of $\mathrm{N}_{\min }$ and $Q_{10}$. The results showed that the average $\mathrm{N}_{\text {min }}$ was $2.78 \pm 0.18 \mathrm{mg} \mathrm{N} \mathrm{kg}^{-1} \mathrm{~d}^{-1}$ at an incubation conditions of $25^{\circ} \mathrm{C}$ across Chinese terrestrial ecosystems, and it decreased gradually with increasing latitude $(P<0.01)$. The $\mathrm{N}_{\text {min }}$ values were the highest in farmlands $\left(3.08 \pm 0.20 \mathrm{mg} \mathrm{N} \mathrm{kg}^{-1} \mathrm{~d}^{-1}\right)$, followed by forests $\left(2.35 \pm 0.42 \mathrm{mg} \mathrm{N} \mathrm{kg}^{-1}\right.$ $\left.\mathrm{d}^{-1}\right)$ and grasslands $\left(0.57 \pm 0.13 \mathrm{mg} \mathrm{N} \mathrm{kg}^{-1} \mathrm{~d}^{-1}\right)$. The $Q_{10}$ values differed significantly among different ecosystems $(P<0.01)$, with an average of 1.58 . The $Q_{10}$ values increased significantly with increasing latitude, supporting the hypothesis that the $Q_{10}$ values are higher in colder regions. Path analysis showed that $\mathrm{N}_{\min }$ is mainly affected by mean annual temperature and SOM content, whereas $Q_{10}$ is primarily affected by soil total nitrogen. The activation energy $\left(E_{\mathrm{a}}\right)$ of $\mathrm{N}_{\min }$ and substrate quality index (A) was strongly negatively correlated, indicating that the carbon-quality temperature hypothesis is applicable to $\mathrm{N}_{\min }$ at a large spatial scale. These findings provide new evidence that soil $\mathrm{N}$ availability in colder regions is likely to increase due to higher $Q_{10}$ under global warming scenarios, which may promote ecosystem productivity at higher latitudes.
\end{abstract}

(c) 2015 Elsevier B.V. All rights reserved.

\section{Introduction}

The capacity of soil nitrogen (N) supply is a key element influencing plant growth (Näsholm et al., 1998) and limiting primary productivity in most natural ecosystems (Vitousek and Howarth, 1991; Elser et al., 2007). A requirement for $\mathrm{N}$ fertilizer is therefore pervasive in intensive agricultural ecosystems. Soil $\mathrm{N}$ availability is determined to a large extent by the processes of soil $\mathrm{N}$ mineralization $\left(\mathrm{N}_{\min }\right)$, which converts soil organic $\mathrm{N}$ into inorganic $\mathrm{N}$ from soil organic matter (SOM) with the help of soil animals and microorganisms (Chapin III et al., 2011). Some studies have demonstrated that the rates of $\mathrm{N}_{\min }$ are mainly influenced by temperature and tend to increase gradually with increasing

\footnotetext{
* Corresponding author at: Institute of Geographic Sciences and Natural Resources Research, Chinese Academy of Sciences, Beijing 100101, China. Fax: +86 1064889399 .

E-mail address: henp@igsnrr.ac.cn (N. He).
}

temperature in a given temperature range (Sierra, 1997; Guntinas et al., 2012). Under the context of global warming, even a slight change of $\mathrm{N}_{\min }$ in response to temperature shift would affect soil $\mathrm{N}$ availability and thus influence primary productivity to some extent (Stocker et al., 2013). However, since these previous researches were mainly conducted at several sites or within a small region, it remains unclear whether the phenomena or the underlying mechanisms observed at several smaller sites are applicable at the large scale.

Temperature affects the processes of $\mathrm{N}_{\text {min }}$ through altering the community composition and quantity of soil microorganisms (Guntinas et al., 2012). The temperature sensitivity of $N_{\min }\left(Q_{10}\right)$ has been widely used as an important ecological parameter in models of carbon (C) and $\mathrm{N}$ cycles to depict the responses of $\mathrm{N}_{\min }$ with an increase in temperature of $10^{\circ} \mathrm{C}$ (Reichstein et al., 2005). In earlier models, the $Q_{10}$ values were commonly considered to be constant, with an average of 2 . However, some experiments demonstrated that the $Q_{10}$ values vary spatially among different ecosystems (Lenton and Huntingford, 2003), depending on the 
conditions of soil temperature, soil water content, and SOM quality as well as different vegetation types (Wetterstedt et al., 2010; Craine and Gelderman., 2011; Weedon et al., 2013). Given that these factors are spatially heterogeneous, the $Q_{10}$ values may also vary among different geographic locations. It is expected that even a small deviation of $Q_{10}$ values may result in apparent biases in the estimation of $\mathrm{N}_{\min }$ at a large scale in models. Therefore, understanding the spatial pattern and regulating mechanisms of $N_{\text {min }}$ and $Q_{10}$ is of great significance in order to precisely evaluate the supply of soil available $\mathrm{N}$ and for the sustainable management of anthropogenic ecosystems.

Few studies have investigated changes in the $Q_{10}$ values of $N_{\text {min }}$ with respect to large-scale environmental variations, although several investigations have been conducted with regards to the spatial patterns of $Q_{10}$ for soil C mineralization or respiration (Davidson and Janssens, 2006; Peng et al., 2009; Song et al., 2014). Furthermore, the carbon-quality temperature hypothesis (CQT) was proposed to explain the underlying mechanisms of SOM decomposition on the basis of enzyme kinetics principles; that is, with more biochemical recalcitrant SOM, the $Q_{10}$ for soil microbial respiration is greater (Bosatta and Agren, 1999). This hypothesis has been verified both directly and indirectly with respect to soil C mineralization or soil respiration (Fierer et al., 2005; Conant et al., 2008; Craine et al., 2010; Wang et al., 2014). Recent studies have demonstrated that soil $\mathrm{C}$ and $\mathrm{N}$ mineralization are closely coupled, irrespective of vegetation types (Quan et al., 2014; Gutiérrez-Girón et al., 2015). However, it remains unclear whether the CQT hypothesis is applicable to soil $\mathrm{N}$ mineralization, especially at a regional or global scale.

Here, we collected 212 published papers on soil N mineralization in Chinese terrestrial ecosystems, and categorized the data to explore the spatial patterns and regulating mechanisms of $\mathrm{N}_{\text {min }}$ and $Q_{10}$. The main objectives of this study were to: (1) investigate the spatial patterns and regulating factors of $N_{\min }$ and $Q_{10},(2)$ explore the underlying mechanism of $N_{\text {min }}$ and $Q_{10}$ at a regional scale, and (3) evaluate whether the CQT hypothesis is applicable to soil $\mathrm{N}$ mineralization at a regional scale.

\section{Methods}

\subsection{Data collection}

We compiled the available data of soil $\mathrm{N}$ mineralization rates in Chinese terrestrial ecosystems from papers published from 1990 to 2014, which were downloaded from the Web of Science (www.webofknowledge.com) and China National Knowledge Infrastructure (http://epub.cnki.net) databases. Only published data from laboratory experiments were extracted for the analysis of potential $\mathrm{N}_{\text {min }}$ at $25^{\circ} \mathrm{C}$ incubation. Furthermore, data from experiments using different incubation temperatures were collected to calculate the $Q_{10}$ values of $N_{\text {min. }}$. In total, data from 167 published papers were used to investigate $\mathrm{N}_{\text {min }}$ at $25^{\circ} \mathrm{C}$ (Fig. 1 A and Table S1), and data from 60 published papers were used to calculate the $Q_{10}$ values among Chinese terrestrial ecosystems (Fig. 1B and Table S2).

The original data were first extracted from tables or graphs using the GetData Graph Digitizer software (version 2.24, Russian Federation). Furthermore, auxiliary information was collected, such as longitude, latitude, altitude, mean annual temperature (MAT), mean annual precipitation (MAP), ecosystem type, $\mathrm{pH}, \mathrm{SOM}$ content, and soil total nitrogen (TN). The forest data were divided into the following four types according to their morphological features in order to explore the influence of forest types on $\mathrm{N}_{\text {min }}$ and $Q_{10}$ : deciduous coniferous forest (DCF), evergreen coniferous forest (ECF), deciduous broadleaved forest (DBF), and evergreen broadleaved forest (EBF).

\subsection{Data calculations}

The potential rates of soil $\mathrm{N}_{\text {min }}$ under $25^{\circ} \mathrm{C}$ incubation were selected to depict the spatial patterns of soil $\mathrm{N}$ mineralization, because $25^{\circ} \mathrm{C}$ is considered as the optimal incubation temperature for microbe growth and activity (Wang et al., 2006). The average $\mathrm{N}_{\text {min }}$ for a specific site was used when soils were incubated at different soil water content.

The $Q_{10}$ values were calculated according to Eq. (1) (Janssens and Pilegaard, 2003):

$Q_{10}=\left(\frac{\mathrm{RN}_{2}}{\mathrm{RN}_{1}}\right)^{\left[10 /\left(T_{2}-T_{1}\right)\right]}$

where $\mathrm{RN}_{1}$ and $\mathrm{RN}_{2}$ are the soil net $\mathrm{N}$ mineralization rates ( $\mathrm{mg} \mathrm{N} \mathrm{kg}^{-1} \mathrm{~d}^{-1}$ ) at incubation temperatures $T_{1}$ and $T_{2}$, respectively.

The apparent activation energy $\left(E_{\mathrm{a}}, \mathrm{kJ} \mathrm{mol}^{-1}\right)$ of soil $\mathrm{N}_{\text {min }}$ rate, as an enzyme kinetic parameter representing the difficulty of a reaction, was calculated using the Arrhenius equation as shown in Eq. (2) (Hamdi et al., 2013):

$\mathrm{RN}=\mathrm{A} \times \mathrm{e}^{-E_{\mathrm{a}} / R T}$

where $\mathrm{RN}$ represents the soil net $\mathrm{N}$ mineralization rate $(\mathrm{mgN}$ $\left.\mathrm{kg}^{-1} \mathrm{~d}^{-1}\right), \mathrm{A}$ is a pre-exponential factor known as the substrate
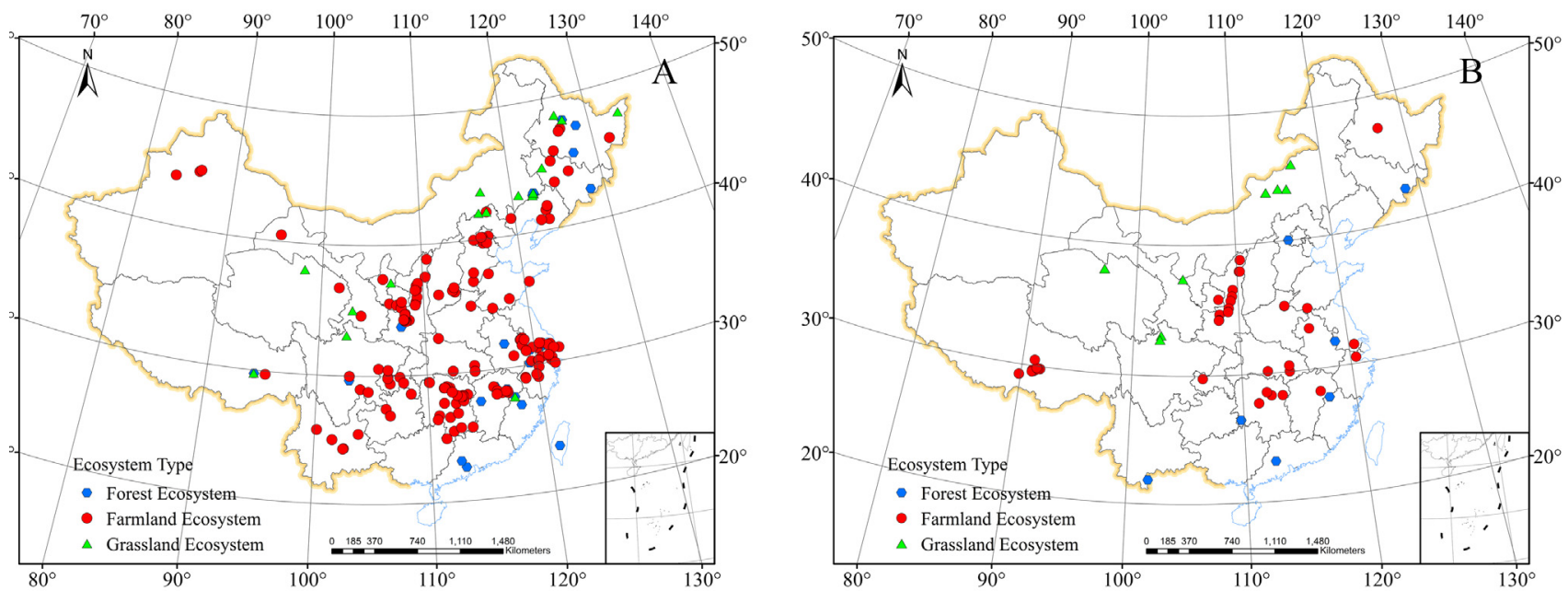

Fig. 1. Spatial distribution of sampling sites from published articles focusing on soil net nitrogen mineralization rates (A) and temperature sensitivity (B). 
Table 1

Soil nitrogen mineralization rates $\left(\mathrm{N}_{\mathrm{min}}\right)$, temperature sensitivity $\left(Q_{10}\right)$, and activation energy $\left(E_{\mathrm{a}}\right)$ among different ecosystems in China (mean $\pm \mathrm{SE}$ ).

\begin{tabular}{|c|c|c|c|c|c|c|}
\hline \multirow[b]{2}{*}{ Ecosystem types } & \multicolumn{2}{|l|}{$\begin{array}{l}\mathrm{N}_{\min } \\
\left(\mathrm{mg} \mathrm{kg}^{-1} \mathrm{~d}^{-1}\right)\end{array}$} & \multicolumn{2}{|l|}{$Q_{10}$} & \multicolumn{2}{|l|}{$E_{\mathrm{a}}\left(\mathrm{kJ} \mathrm{mol}^{-1}\right)$} \\
\hline & Mean & $\mathrm{N}^{\mathrm{a}}$ & Mean & $\mathrm{N}$ & Mean & $N$ \\
\hline Forest & $2.35 \pm 0.42 \mathrm{a}^{*}$ & 36 & $1.94 \pm 0.20 a$ & 11 & $39.43 \pm 6.48 a$ & 11 \\
\hline Farmland & $3.08 \pm 0.20 \mathrm{a}$ & 201 & $1.45 \pm 0.04 b$ & 41 & $23.73 \pm 1.86 b$ & 38 \\
\hline Grassland & $0.57 \pm 0.13 b$ & 21 & $1.78 \pm 0.14 \mathrm{ab}$ & 8 & $53.83 \pm 14.53 a$ & 6 \\
\hline Total & $2.78 \pm 0.18$ & 258 & $1.58 \pm 0.05$ & 60 & $30.15 \pm 2.70$ & 55 \\
\hline $\mathrm{F}$ & 8.45 & & 9.35 & & 9.67 & \\
\hline$P$ & $<0.01$ & & $<0.01$ & & $<0.01$ & \\
\hline
\end{tabular}

${ }^{\mathrm{a}} \mathrm{N}$ : number of samples.

"Data with the same letters indicate no significant difference among different ecosystem types at $P<0.05$.

quality index (Craine et al., 2010), $R$ is the gas constant $(8.314 \mathrm{~J}$ $\mathrm{mol}^{-1} \mathrm{~K}^{-1}$ ), and $T$ is temperature in Kelvin (K).

\subsection{Statistical analyses}

The normality of the data was evaluated using the KolmogorovSmirnov test, and we used a logarithmic transformation to stabilize the distribution to approximate normality. Differences in the potential rate of soil $\mathrm{N}_{\text {min }}$ at $25^{\circ} \mathrm{C}$ and $Q_{10}$ among different ecosystems were tested using one-way analysis of variance (ANOVA), with least significant differences (LSD) for multiple comparisons. Regression and correlation analyses were used to determine the relationships of TN, SOM, and $\mathrm{pH}$ with $\mathrm{N}_{\min }$ or $Q_{10}$. Path analyses were used to evaluate the main factors influencing $\mathrm{N}_{\text {min }}$ and $Q_{10}$. Differences were considered significant at $P<0.05$. All statistical analyses were conducted using SPSS software (SPSS for Windows, Version 13.0, Chicago, IL, USA).

\section{Results}

\subsection{Changes in $N_{\min }$ among different ecosystems}

$\mathrm{N}_{\text {min }}$ varied both within and among ecosystem types ranging from -0.60 to $15.47 \mathrm{mg} \mathrm{N} \mathrm{kg}^{-1} \mathrm{~d}^{-1}$ (Table 1 ). The $\mathrm{N}_{\min }$ values were not significantly different among different forest types (Fig. S1A). However, $\mathrm{N}_{\text {min }}$ differed significantly among different ecosystems $(P<0.01)$ with an average of $2.78 \mathrm{mg} \mathrm{N} \mathrm{kg}^{-1} \mathrm{~d}^{-1}$ for forests, grasslands, and farmlands in China (Table 1 ). $\mathrm{N}_{\text {min }}$ was significantly higher in farmlands $\left(3.08 \mathrm{mg} \mathrm{N} \mathrm{kg}^{-1} \mathrm{~d}^{-1}\right)$ and forests $(2.35 \mathrm{mg} \mathrm{N}$ $\left.\mathrm{kg}^{-1} \mathrm{~d}^{-1}\right)$ than in grasslands $\left(0.57 \mathrm{mg} \mathrm{N} \mathrm{kg}^{-1} \mathrm{~d}^{-1}\right)$, but the differences between forests and farmlands were not statistically significant at $P=0.05$ level.

\subsection{Changes in $\mathrm{Q}_{10}$ and $\mathrm{E}_{\mathrm{a}}$ among different ecosystems}

The $Q_{10}$ values varied remarkably among different terrestrial ecosystems $(P<0.01$; Table 1$)$, ranging from 0.9 to 3.1 (mean 1.58; Fig. 2) with means of $1.9,1.5$, and 1.8 in forests, farmlands, and grasslands, respectively (Table 1 ). Within forest ecosystems, the $Q_{10}$ values of ECF were significantly higher than those of DBF and EBF (Fig. S1B).

The values of $E_{\mathrm{a}}$ were significantly different among diverse ecosystems $(P<0.01)$, with the highest $E_{\mathrm{a}}$ values observed in grasslands $\left(53.8 \mathrm{~kJ} \mathrm{~mol}^{-1}\right)$, followed by forests $\left(39.4 \mathrm{~kJ} \mathrm{~mol}^{-1}\right)$ and farmlands $\left(23.7 \mathrm{~kJ} \mathrm{~mol}^{-1}\right.$ ) (Table 1$)$. Furthermore, the values of $E_{\mathrm{a}}$ were significantly negatively correlated with substrate quality (A) (Fig. $3, R^{2}=0.404, P<0.001$ ), which verified the applicability of the CQT hypothesis to soil $\mathrm{N}_{\min }$ at a large scale.

\subsection{Spatial patterns and regulating factors of $N_{\min }$ and $\mathrm{Q}_{10}$}

There was a strong negative relationship between $\mathrm{N}_{\min }$ and latitude $\left(R^{2}=0.327, P<0.001\right)$, and $\mathrm{N}_{\text {min }}$ significantly decreased with increasing latitude (Fig. 4A). However, no apparent longitudinal patterns were observed. Moreover, $\mathrm{N}_{\text {min }}$ was significantly negatively associated with altitude, with $\mathrm{N}_{\text {min }}$ logarithmically decreasing with increasing altitude (Fig. 5A). Table 2 provides the correlations between $\mathrm{N}_{\min }$ and the selected environmental factors. $\mathrm{N}_{\text {min }}$ significantly increased with increasing $\mathrm{TN}$ and SOM, but decreased with increasing $\mathrm{pH}$ (Fig. 6A, C, E). Path analyses demonstrated that MAT and SOM content were the dominant factors influencing $\mathrm{N}_{\min }$ (Table 3 ).

As expected, the $Q_{10}$ values showed significant spatial patterns across the Chinese terrestrial ecosystems (Fig. 4 ), in which the $Q_{10}$ values significantly increased with increasing latitude $\left(R^{2}=0.202\right.$, $P<0.01)$ but not with longitude $\left(R^{2}=0.008, P>0.05\right)$. Moreover, the $Q_{10}$ values were significantly affected by altitude, with a dramatically linear decrease in $Q_{10}$ with increasing altitude (Fig. 5B). The $Q_{10}$ values also significantly increased with increasing TN $\left(R^{2}=0.363, P<0.01\right.$, Fig. $\left.6 \mathrm{~B}\right)$ and SOM $\left(R^{2}=0.216, P<0.01\right.$, Fig. 6D); however, the relationships between $Q_{10}$ and $\mathrm{pH}$ were not significant (Table 4, Fig. 6E). The results of path analyses showed that $\mathrm{TN}$ was the primary factor influencing $Q_{10}$, and accounted for $56 \%$ of the total variation.

\section{Discussion}

\subsection{The spatial patterns and main factors regulating $N_{\min }$}

The potential of soil nitrogen mineralization $\left(\mathrm{N}_{\min }\right)$ among all ecosystems significantly decreased with increasing latitude and
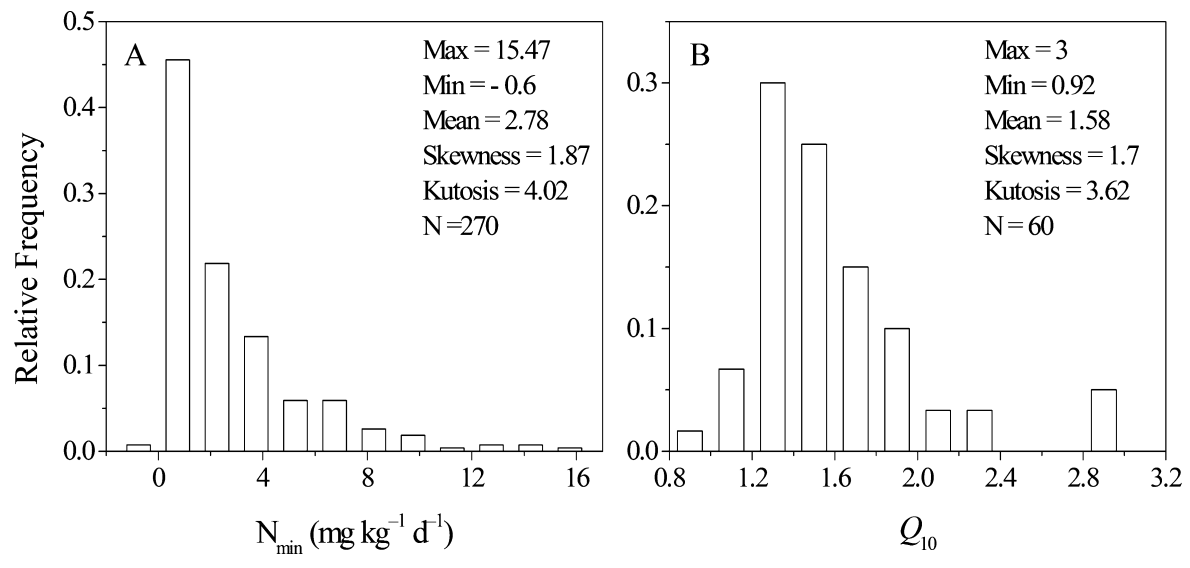

Fig. 2. Frequency distributions of soil net nitrogen mineralization rates $\left(N_{\min }, A\right)$ and temperature sensitivity $\left(Q_{10}\right.$, $\left.B\right)$. 


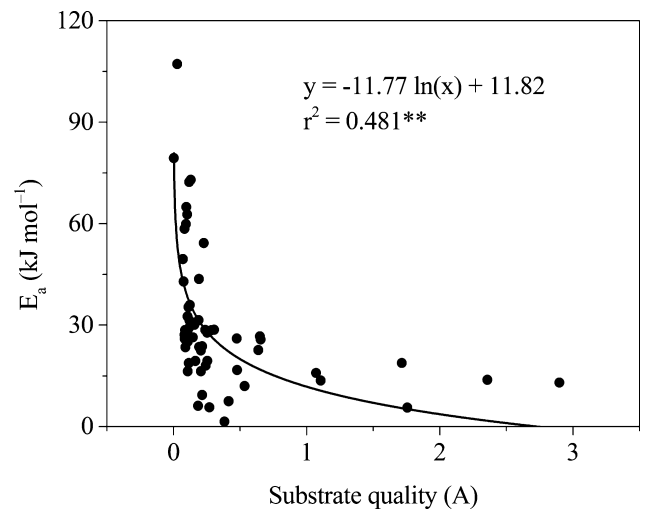

Fig. 3. Relationships between activation energy $\left(E_{\mathrm{a}}\right)$ and substrate quality (A). *** Represents a significant correlation at $P<0.001$.

altitude. In other words, decreases in $\mathrm{N}_{\text {min }}$ resulted from a decrease in MAT at higher latitude and altitude region. Through a metaanalysis, Rustad et al. (2001) demonstrated that $\mathrm{N}_{\text {min }}$ was significantly negatively correlated with latitude, which was caused by the decrease in microbial populations and activities owing to the decrease of temperature and precipitation. Lower temperature is the major limiting factor for plant root growth and soil microbial activities in colder regions (Zheng et al., 2009), which indirectly lead to the lower $\mathrm{N}_{\min }$ observed in these regions. However, the reported results were obtained from laboratory incubation studies, and the accumulation of SOM in soils of colder regions is limited because of microbial decomposition due to lower temperature; therefore, $\mathrm{N}_{\mathrm{min}}$ at colder sites would be overestimated based on laboratory incubations to some extent. Zhang et al. (2012) found that increasing $\mathrm{C}$ : $\mathrm{N}$ ratios in SOM increased in alpine meadows with increasing altitude, resulting in a lower $\mathrm{N}_{\text {min }}$. Furthermore, colder regions accumulate total organic matter but not labile organic matter. In a field experiment, Gutiérrez-Girón et al. (2015) found that labile soil organic carbon (such as dissolved organic carbon and microbial biomass) gradually decreased with increasing altitude, and $\mathrm{N}_{\min }$ reduced at higher altitude sites owing to decreasing substrate availability. Soil properties (e.g., SOM, TN, and $\mathrm{pH}$ ) also affect the process of soil $\mathrm{N}$ mineralization. The results of path analyses demonstrated that SOM content is an important

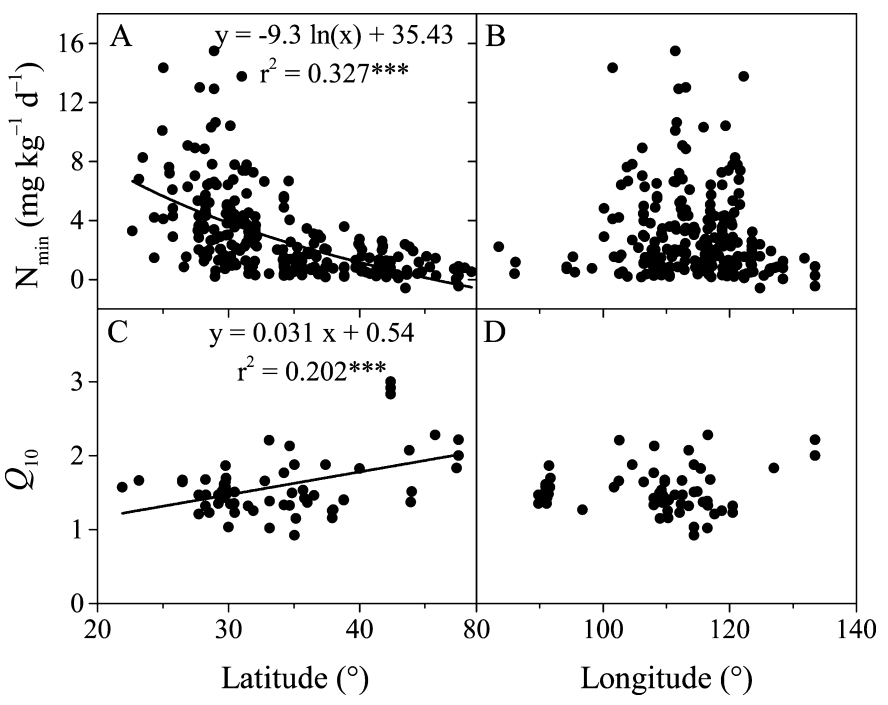

Fig. 4. Changes in soil net nitrogen mineralization rates $\left(\mathrm{N}_{\min }\right)$ and temperature sensitivity $\left(Q_{10}\right)$ with latitude and longitude. ${ }^{*}$ and ${ }^{* * *}$ represent a significant relationship at 0.05 and $P<0.001$, respectively.

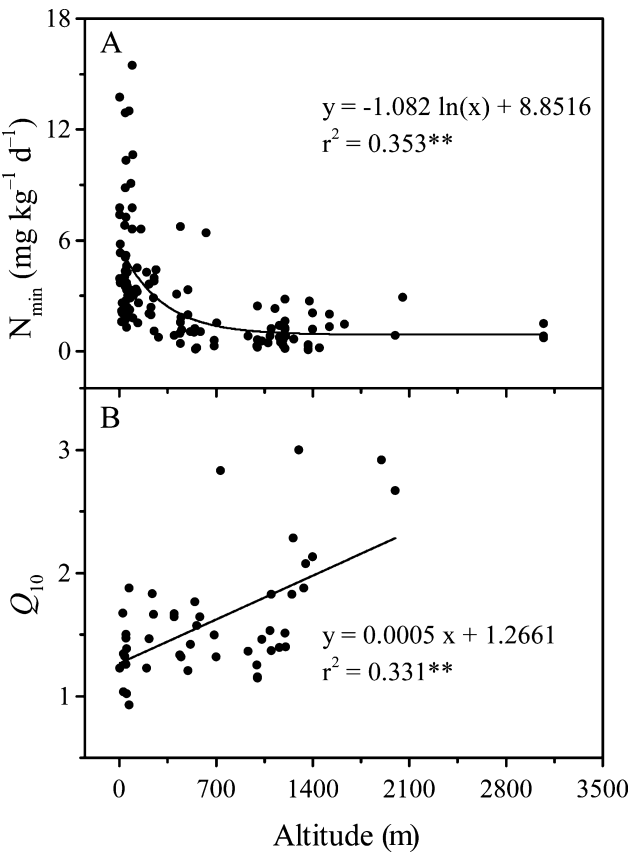

Fig. 5. Changes in soil net nitrogen mineralization rates $\left(\mathrm{N}_{\min }\right)$ and temperature sensitivity $\left(Q_{10}\right)$ with altitude. ${ }^{* *}$ represents a significant relationship at $P<0.01$.

factor regulating the large-scale spatial patterns of $\mathrm{N}_{\text {min }}$. Bai et al. (2005) reported that $\mathrm{N}_{\text {min }}$ was significantly positively correlated with SOM and increased with the substrate supply. Colman and Schimel (2013) demonstrated that SOM quality could explain a relatively large proportion of variation in $\mathrm{N}_{\text {min }}$.

Furthermore, $\mathrm{N}_{\text {min }}$ was significantly negatively correlated with soil $\mathrm{pH}$ in this study, which is consistent with a previous incubation study (Cheng et al., 2013). Soil $\mathrm{pH}$ has a strong influence on $\mathrm{N}_{\text {min }}$ through its effects on the composition and activity of microbial communities and soil substrate availability (Priha et al., 2001). Changes in soil $\mathrm{pH}$ may in turn influence both soil gross $\mathrm{N}$ mineralization and immobilization rates, resulting in a declining tendency in $\mathrm{N}_{\min }$ with increasing $\mathrm{pH}$ (from 3.8 to 6.8 ) in forest soils (Cheng et al., 2013). By contrast, Fu et al. (1987) reported that $\mathrm{N}_{\text {min }}$ increased with an increase in soil $\mathrm{pH}$ due to the promoting effects of high pH on substrate availability, and Kemmitt et al. (2006) found that both soil $\mathrm{N}$ mineralization and nitrification rates were positively correlated with $\mathrm{pH}$, since soil acidity limits soil microbial activity. The contrasting effects of $\mathrm{pH}$ on $\mathrm{N}_{\min }$ may relate to the different effects of soil $\mathrm{pH}$ on gross $\mathrm{N}$ mineralization and gross $\mathrm{N}$ immobilization, because microbial populations are responsible for both the release and immobilization of nutrients in soils.

Table 2

Pearson correlation coefficients $(r)$ between soil properties and soil net nitrogen mineralization rates $\left(\mathrm{N}_{\mathrm{min}}\right)$.

\begin{tabular}{lllllll}
\hline & MAT & MAP & TN & SOM & pH & $\mathrm{N}_{\text {min }}$ \\
\hline MAT & 1.00 & & & & & \\
MAP & $0.76^{* *}$ & 1.00 & & & & \\
TN & 0.10 & $0.32^{* *}$ & 1.00 & & & \\
SOM & $-0.14^{* * *}$ & $0.13^{* * * *}$ & $0.66^{* * *}$ & 1.00 & & \\
pH & $-0.33^{* *}$ & $-0.68^{* *}$ & $-0.29^{* *}$ & $-0.30^{* *}$ & 1.00 & \\
$\mathrm{~N}_{\text {min }}$ & $0.45^{* *}$ & $0.49^{* *}$ & $0.35^{* *}$ & $0.31^{* *}$ & $-0.35^{* *}$ & 1.00 \\
\hline
\end{tabular}

MAT, mean annual air temperature; MAP, mean annual precipitation; TN, soil total nitrogen; SOM, soil organic matter; $\mathrm{N}_{\min }$, soil net nitrogen mineralization rates.

* Significant at $P<0.05$,

Significant at $P<0.001$. 

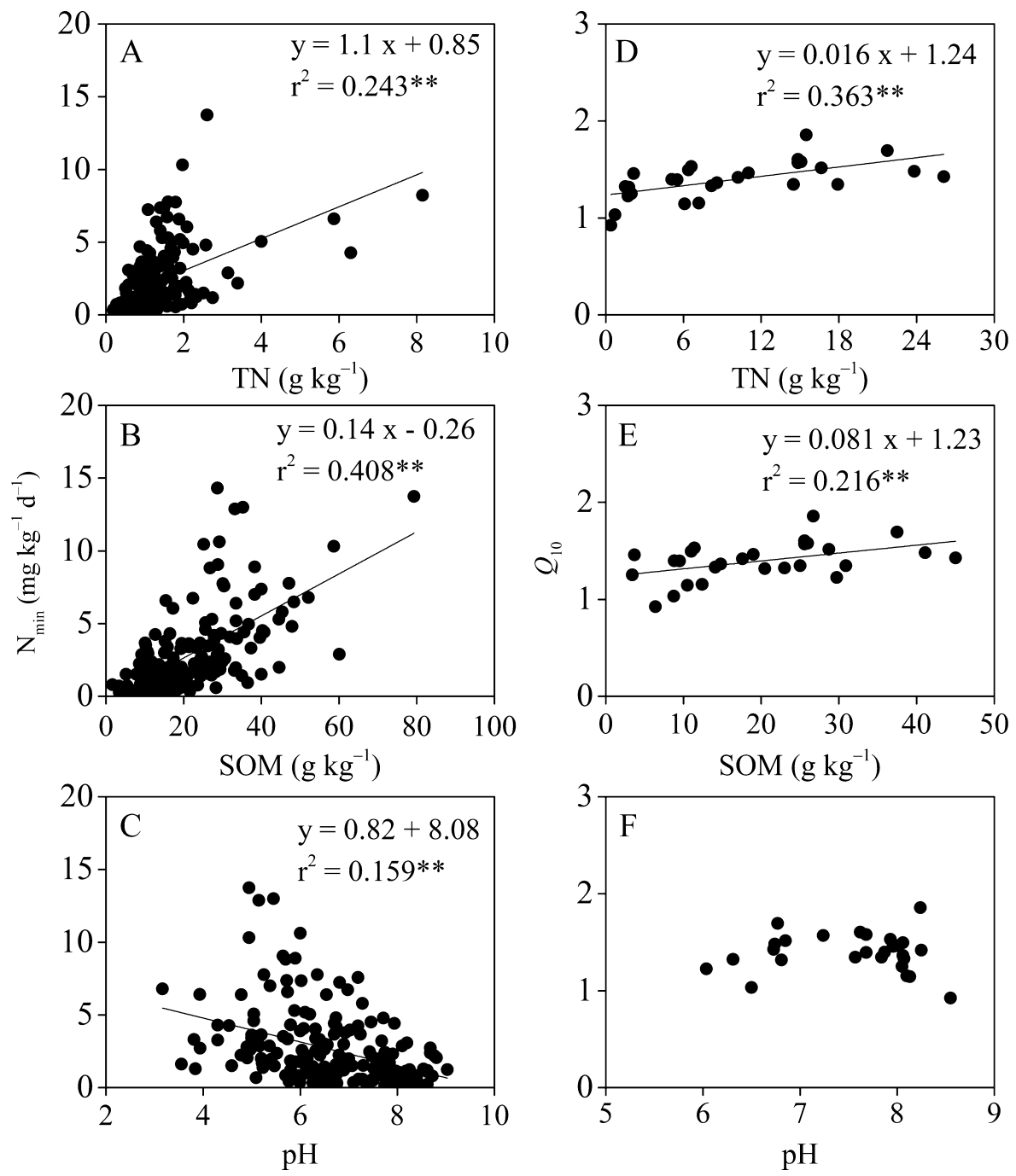

Fig. 6. Influence of different environmental factors on soil net nitrogen mineralization rates $\left(N_{\text {min }}\right)$ and temperature sensitivity $\left(Q_{10}\right)$.

\subsection{The spatial patterns and factors regulating $\mathrm{Q}_{10}$}

The $Q_{10}$ values increased with increasing latitude and altitude, but there was no significant relationship between $Q_{10}$ and longitude. The lower $Q_{10}$ at lower latitudes might result from the adaptation of microorganisms to the increased temperature in these regions (Santruckova et al., 2003; Wang et al., 2007). Tjoelker et al. (2001) reported that the $Q_{10}$ values of soil C mineralization were significantly negatively correlated with soil temperature, and decreased with increasing soil temperature in experiments conducted at different latitudes (arctic, cool-temperate zone, temperate zone, and tropical zone). Similar relationships between the $Q_{10}$ of soil C mineralization and temperature were reported in

Table 3

Results of path analysis between soil properties and $\mathrm{N}_{\min }$ and $Q_{10}$.

\begin{tabular}{lllllll}
\hline & MAT & MAP & TN & SOM & pH \\
\hline $\mathrm{N}_{\text {min }}$ & $\begin{array}{l}\text { path coefficient } \\
\text { order }\end{array}$ & $0.395^{*}$ & 0.101 & 0.074 & $0.288^{*}$ & -0.04 \\
& 1 & 3 & 4 & 2 & 5 \\
$\mathrm{Q}_{10}$ & $\begin{array}{l}\text { path coefficient } \\
\text { order }\end{array}$ & $-0.130^{*}$ & $-0.243^{*}$ & $0.559^{*}$ & 0.036 & -0.01 \\
& 3 & 2 & 1 & 4 & 5 \\
\hline
\end{tabular}

MAT, mean annual air temperature; MAP, mean annual precipitation; TN, soil total nitrogen; SOM, soil organic matter; $\mathrm{N}_{\min }$, soil net nitrogen mineralization rates; $Q 10$, temperature sensitivity.

Significant at $P<0.05$ other studies (Chen and Tian, 2005; Koch et al., 2007; Chen et al., 2010; Hamdi et al., 2013). This finding support the hypothesis that the $Q_{10}$ values of $N_{\text {min }}$ are also higher in colder regions, and confirms the close relationships between soil $\mathrm{C}$ and $\mathrm{N}$ mineralization with changing temperature at a large spatial scale (Quan et al., 2014). Similar to latitude, the $Q_{10}$ values linearly increased with increasing altitude in Chinese terrestrial ecosystems. The variation of $Q_{10}$ values along the altitudinal gradient is affected by substrate availability and microbial community composition (Lipson et al., 2002; Lipson, 2007). Moreover, the plant community structure

Table 4

Pearson correlation coefficients $(r)$ between soil properties and temperature sensitivity $\left(Q_{10}\right)$.

\begin{tabular}{lllllll}
\hline & MAT & MAP & TN & SOM & pH & $Q_{10}$ \\
\hline MAT & 1.00 & & & & & \\
MAP & $0.72^{* * *}$ & 1.00 & & & & \\
TN & $-0.77^{* * *}$ & $-0.47^{* *}$ & 1.00 & & & \\
SOM & $-0.47^{* *}$ & -0.08 & $0.83^{* * *}$ & 1.00 & & \\
pH & -0.14 & $-0.53^{* *}$ & -0.16 & $-0.58^{* * *}$ & 1.00 & \\
Q10 & $-0.49^{* *}$ & $-0.41^{* *}$ & $0.60^{* * *}$ & $0.46^{* *}$ & -0.01 & 1.00
\end{tabular}

MAT, mean annual air temperature; MAP, mean annual precipitation; TN, soil total nitrogen; SOM, soil organic matter; $Q_{10}$, Significant at

* Significant at $P<0.05$,

** Significant at $P<0.01$,

Significant at $P<0.001$ 
clearly affects the patterns of $Q_{10}$ with increasing elevation (Gutiérrez-Girón et al., 2015). In addition, longitude may also affect $Q_{10}$ values indirectly through influencing MAP with respect to the decreases of precipitation from the southeast to northwest of China. However, our results indicated that the effect of longitude on $Q_{10}$ values was not significant. Changes of other factors associated with longitude (such as vegetation cover, temperature, and altitude) may conceal the longitudinal patterns of $Q_{10}$ values to some extent. The observed spatial patterns of $Q_{10}$ indicated that under scenarios of global warming, a stronger response of SOM decomposition in colder regions would promote $\mathrm{N}_{\min }$ and enhance primary productivity by alleviating the limitation of soil available N.

The results of path analyses showed that TN was the main factor contributing to the patterns of $Q_{10}$, accounting for $56 \%$ of the variation in $Q_{10}$ values. It is assumed that TN and SOM have a strong influence on the $Q_{10}$ values of soil $\mathrm{N}$ mineralization by regulating the substrates supply of microorganisms. As lower temperatures limit litter decomposition, high-latitude regions always have a higher SOM content (Santruckova et al., 2003), resulting in a consequent increase of $Q_{10}$ with latitude. Zheng et al. (2009) demonstrated that $Q_{10}$ tended to be higher in ecosystems with higher SOM contents, and the quality and quantity of SOM have also been shown to influence its decomposition (Fierer et al., 2005; Knorr et al., 2005).

\subsection{Changes in $\mathrm{N}_{\min }$ and $\mathrm{Q}_{10}$ among different ecosystem types}

The potentials of soil $\mathrm{N}$ mineralization rates $\left(\mathrm{N}_{\min }\right.$ at $\left.25^{\circ} \mathrm{C}\right)$ of farmlands and forests were significantly higher than those of grasslands (Fig. 3); however, the differences were not significant among different forest types; These results are consistent with those of previous incubation studies (Templer et al., 2005; Yang et al., 2008). The observed differences most likely resulted from differences in the quality and quantity of the litter, microbial structure, and abundance, as well as soil physical and chemical properties in different ecosystems (Knoepp and Swank, 1998; Sun et al., 2013). Furthermore, the disruption of soil aggregates by cultivation (Saggar et al., 2001; Arevalo et al., 2012), accompanied by the use of fertilizer, would result in a higher $\mathrm{N}_{\text {min }}$ in farmland soils. Yang et al. (2008) reported that the conversion of natural ecosystems to cropland significantly increased $\mathrm{N}_{\min }$ in Tibet, with averages of $1.48,0.83$, and $0.72 \mathrm{mg} \mathrm{N} \mathrm{kg}^{-1} \mathrm{~d}^{-1}$ in farmland, forest, and grassland, respectively. The lower $\mathrm{N}_{\text {min }}$ in grassland might result from the lower microbial biomass $C$ of grassland soils $\left(206 \mathrm{mg} \mathrm{C} \mathrm{kg}^{-1}\right)$ compared to those of forest soils $\left(516 \mathrm{mg} \mathrm{C} \mathrm{kg}^{-1}\right)$ and cropland (316 $\mathrm{mg} \mathrm{C} \mathrm{kg}^{-1}$ ). Furthermore, the lower $\mathrm{N}_{\min }$ in forest and grassland ecosystems might be due to the immobilization of inorganic $\mathrm{N}$ into biomass by soil microbial communities (Rhoades and Coleman, 1999; Barger et al., 2004). Furthermore, $\mathrm{NO}_{3}{ }^{-}-\mathrm{N}$ accounted for $70-90 \%$ of soil mineralized $\mathrm{N}$, and the higher rates of soil net nitrification in farmland soils suggested that land use change from forest to farmland may lead to higher $\mathrm{N}$ losses through leaching. It is therefore imperative to emphasize the potential change of soil $\mathrm{N}$ dynamics for agricultural management, in order to reduce soil $\mathrm{N}$ loss for the sustainable development of agricultural ecosystems.

The $Q_{10}$ values were significantly lower in farmland than in forest and grassland ecosystems. On the basis of the fundamental principles of enzyme kinetics, the CQT hypothesis predicts that the $Q_{10}$ values of soil $\mathrm{N}$ mineralization should increase with increasing $E_{a}$ (Bosatta and Agren, 1999). Therefore, the enzymatic decomposition of biochemically recalcitrant substrates (i.e., those that require a high $E_{\mathrm{a}}$ to degrade) should generally be more sensitive to changes in temperature than the decomposition of more labile substrates. Our results also showed a significant negative relationship between $E_{\mathrm{a}}$ and substrate quality (i.e., substrates of lower quality require a higher $E_{\mathrm{a}}$, resulting in higher $Q_{10}$ values of a reaction), which indirectly verified the applicability of the CQT hypothesis to soil $\mathrm{N}$ mineralization at a large scale (Craine et al., 2010). The disruption of soil aggregates by cultivation will promote the decomposition of recalcitrant SOM and facilitate the release of labile organic $N$, resulting in lower $Q_{10}$ values in farmland. Therefore, these results indicate that SOM decomposition in agricultural ecosystems would be less sensitive to temperature change under a global warming scenario.

\section{Conclusions}

In this study, the variations, patterns and regulating mechanisms of $N_{\text {min }}$ and $Q_{10}$ were analyzed among diverse Chinese terrestrial ecosystems. Estimated $N_{\min }$ and $Q_{10}$ values are highly spatially heterogeneous and are influenced by multiple factors. $\mathrm{N}_{\text {min }}$ decreased gradually with increasing latitudes and altitudes, whereas $Q_{10}$ increased significantly with increasing latitude and altitude in Chinese terrestrial ecosystems. In general, $\mathrm{N}_{\min }$ was higher in farmland ecosystems, yet $Q_{10}$ was the lowest in these environments. In addition, our findings demonstrated that $Q_{10}$ values are higher in colder regions, which verified that the CQT hypothesis is also applicable to soil $\mathrm{N}$ mineralization at a large spatial scale. The SOM content was the dominant factor influencing $\mathrm{N}_{\text {min }}$, whereas TN was the main factor influencing $Q_{10}$. The higher $Q_{10}$ in colder regions indicates that elevated temperatures are expected to promote soil $\mathrm{N}$ mineralization and enhance the primary productivity of terrestrial ecosystems in the future.

\section{Acknowledgments}

Funding for this work came from the Natural Science Foundation of China (31270519, 31290221, 31470506), by the Chinese Academy of Sciences Strategic Priority Research ProgramXDA05050702, and by the Program for Kezhen Distinguished Talents in Institute of Geographic Sciences and Natural Resources Research, CAS (2013RC102).

\section{Appendix A. Supplementary data}

Supplementary data associated with this article can be found, in the online version, at http://dx.doi.org/10.1016/j.agee.2015.09.012.

\section{References}

Arevalo, C.B.M., Chang, S.X., Bhatti, J.S., Sidders, D., 2012. Mineralization potential and temperature sensitivity of soil organic carbon under different land uses in the parkland region of Alberta, Canada. Soil Sci. Soc. Am. J. 76, 241-251.

Bai, J.H., Ouyang, H., Deng, W., Wang, Q.G., Chen, H., Zhou, C.P., 2005. Nitrogen mineralization processes of soils from natural saline-alkalined wetlands, Xianghai National Nature Reserve, China. Can. J. Soil Sci. 85, 359-367.

Barger, N.N., Ojima, D.S., Belnap, J., Wang, S.P., Wang, Y.F., Chen, Z.Z., 2004. Changes in plant functional groups, litter quality, and soil carbon and nitrogen mineralization with sheep grazing in an Inner Mongolian Grassland. J. Range Manage. 57, 613-619.

Bosatta, E., Agren, G.I., 1999. Soil organic matter quality interpreted thermodynamically. Soil Biol. Biochem. 31, 1889-1891.

Chapin III, F.S., Chapin, M.C., Matson, P.A., Vitousek, P., 2011. Principles of Terrestrial Ecosystem Ecology. Springer.

Chen, H., Tian, H.Q., 2005. Does a general temperature-dependent Q10 model of soil respiration exist at biome and global scale. J. Integr. Plant Biol. 47, 12881302.

Chen, B.Y., Liu, S.R., Ge, J.P., Chu, J.X., 2010. Annual and seasonal variations of Q10 soil respiration in the sub-alpine forests of the Eastern Qinghai-Tibet Plateau, China. Soil Biol. Biochem. 42, 1735-1742.

Cheng, Y., Wang, J., Mary, B., Zhang, J.B., Cai, Z.C., Chang, S.X., 2013. Soil pH has contrasting effects on gross and net nitrogen mineralizations in adjacent forest and grassland soils in central Alberta, Canada. Soil Biol. Biochem. 57, 848-857.

Colman, B.P., Schimel, J.P., 2013. Drivers of microbial respiration and net N mineralization at the continental scale. Soil Biol. Biochem. 60, 65-76. 
Conant, R.T., Drijber, R.A., Haddix, M.L., Parton, W.J., Paul, E.A., Plante, A.F., Six, J., Steinweg, J.M., 2008. Sensitivity of organic matter decomposition to warming varies with its quality. Global Change Biol. 14, 868-877.

Craine, J.M., Gelderman, T.M., 2011. Soil moisture controls on temperature sensitivity of soil organic carbon decomposition for a mesic grassland. Soil Biol. Biochem. 43, 455-457.

Craine, J.M., Fierer, N., McLauchlan, K.K., 2010. Widespread coupling between the rate and temperature sensitivity of organic matter decay. Nat. Geosci. 3, 854857.

Davidson, E.A., Janssens, I.A., 2006. Temperature sensitivity of soil carbon decomposition and feedbacks to climate change. Nature 440, 165-173.

Elser, J.J., Bracken, M.E.S., Cleland, E.E., Gruner, D.S., Harpole, W.S., Hillebrand, H., Ngai, J.T., Seabloom, E.W., Shurin, J.B., Smith, J.E., 2007. Global analysis of nitrogen and phosphorus limitation of primary producers in freshwater, marine and terrestrial ecosystems. Ecol. Lett. 10, 1135-1142.

Fierer, N., Craine, J.M., McLauchlan, K., Schimel, J.P., 2005. Litter quality and the temperature sensitivity of decomposition. Ecology 86, 320-326.

Fu, M.H., Xu, X.C., Tabatabai, M.A., 1987. Effect of pH on nitrogen mineralization in crop-residue-treated soils. Biol. Fertil. Soils 5, 115-119.

Guntinas, M.E., Leiros, M.C., Trasar-Cepeda, C., Gil-Sotres, F., 2012. Effects of moisture and temperature on net soil nitrogen mineralization: A laboratory study. Eur. J. Soil Biol. 48, 73-80.

Gutiérrez-Girón, A., Díaz-Pinés, E., Rubio, A., Gavilán, R.G., 2015. Both altitude and vegetation affect temperature sensitivity of soil organic matter decomposition in Mediterranean high mountain soils. Geoderma 237, 1-8.

Hamdi, S., Moyano, F., Sall, S., Bernoux, M., Chevallier, T., 2013. Synthesis analysis of the temperature sensitivity of soil respiration from laboratory studies in relation to incubation methods and soil conditions. Soil Biol. Biochem. 58, 115-126.

Janssens, I.A., Pilegaard, K.I.M., 2003. Large seasonal changes in Q10 of soil respiration in a beech forest. Global Change Biol. 9, 911-918.

Kemmitt, S., Wright, D., Goulding, K., Jones, D., 2006. pH regulation of carbon and nitrogen dynamics in two agricultural soils. Soil Biol. Biochem. 38, 898-911.

Knoepp, J.D., Swank, W.T., 1998. Rates of nitrogen mineralization across an elevation and vegetation gradient in the southern Appalachians. Plant Soil 204, 235-241.

Knorr, W., Prentice, I., House, J., Holland, E., 2005. Long-term sensitivity of soil carbon turnover to warming. Nature 433, 298-301.

Koch, O., Tscherko, D., Kandeler, E., 2007. Temperature sensitivity of microbial respiration, nitrogen mineralization, and potential soil enzyme activities in organic alpine soils. Global Biogeochem. Cycle 21, 1-11.

Lenton, T.M., Huntingford, C., 2003. Global terrestrial carbon storage and uncertainties in its temperature sensitivity examined with a simple model. Global Change Biol. 9, 1333-1352.

Lipson, D.A., Schadt, C.W., Schmidt, S.K., 2002. Changes in soil microbial community structure and function in an alpine dry meadow following spring snow melt Microb. Ecol. 43, 307-314.

Lipson, D.A., 2007. Relationships between temperature responses and bacterial community structure along seasonal and altitudinal gradients. FEMS Microbiol. Ecol. 59, 418-427.

Näsholm, T., Ekblad, A., Nordin, A., Giesler, R., Högberg, M., Högberg, P., 1998. Boreal forest plants take up organic nitrogen. Nature 392, 914-916.

Peng, S.S., Piao, S.L., Wang, T., Sun, J.Y., Shen, Z.H., 2009. Temperature sensitivity of soil respiration in different ecosystems in China. Soil Biol. Biochem. 41, 1008-1014.

Priha, O., Grayston, S.J., Hiukka, R., Pennanen, T., Smolander, A., 2001. Microbial community structure and characteristics of the organic matter in soils under Pinus sylvestris, Picea abies and Betula pendula at two forest sites. Biol. Fertil. Soils 33, 17-24.

Quan, Q., Wang, C.H., He, N.P., Zhang, Z., Wen, X.F., Su, H.X., Wang, Q., Xue, J.Y., 2014 Forest type affects the coupled relationships of soil $\mathrm{C}$ and $\mathrm{N}$ mineralization in the temperate forests of northern China. Sci. Rep. 4, 1-8.

Reichstein, M., Subke, J.A., Angeli, A.C., Tenhunen, J.D., 2005. Does the temperature sensitivity of decomposition of soil organic matter depend upon water content, soil horizon, or incubation time? Global Change Biol. 11, 1754-1767.
Rhoades, C.C., Coleman, D.C., 1999. Nitrogen mineralization and nitrification following land conversion in montane Ecuador. Soil Biol. Biochem. 31, 1347-1354.

Rustad, L.E., Campbell, J.L., Marion, G.M., Norby, R.J., Mitchell, M.J., Hartley, A.E., Cornelissen, J.H.C., Gurevitch, J., 2001. Gcte-News,. A meta-analysis of the response of soil respiration, net nitrogen mineralization, and aboveground plant growth to experimental ecosystem warming. Oecologia 126, 543-562.

Saggar, S., Yeates, G.W., Shepherd, T.G., 2001. Cultivation effects on soil biologica properties, microfauna and organic matter dynamics in Eutric Gleysol and Gleyic Luvisol soils in New Zealand. Soil Tillage Res. 58, 55-68.

Santruckova, H., Bird, M.I., Kalaschnikov, Y.N., Grund, M., Elhottova, D., Simek, M., Grigoryev, S., Gleixner, G., Arneth, A., Schulze, E.D., Lloyd, J., 2003. Microbial characteristics of soils on a latitudinal transect in Siberia. Global Change Biol. 9 , $1106-1117$.

Sierra, J., 1997. Temperature and soil moisture dependence of $\mathrm{N}$ mineralization in intact soil cores. Soil Biol. Biochem. 29, 1557-1563.

Song, X.Z., Peng, C.H., Zhao, Z.Y., Zhang, Z.T., Guo, B.H., Wang, W.F., Jiang, H., Zhu, Q. 2014. Quantification of soil respiration in forest ecosystems across China. Atmos. Environ. 94, 546-551.

Stocker, T.F., Qin, D., Plattner, G.K., Tignor, M., Allen, S.K., Boschung, J., Nauels, A., Xia, Y., Bex, B., Midgley, B.M., 2013. Working Group I Contribution to the Fifth Assessment Report of the Intergovernmental Panel on Climate Change, Full WG AR5 Report. IPCC.

Sun, S.H., Liu, J.J., Chang, S.X., 2013. Temperature sensitivity of soil carbon and nitrogen mineralization: impacts of nitrogen species and land use type. Plant Soil 372, 597-608.

Templer, P.H., Groffman, P.M., Flecker, A.S., Power, A.G., 2005. Land use change and soil nutrient transformations in the Los Haitises region of the Dominican Republic. Soil Biol. Biochem. 37, 215-225.

Tjoelker, M.G., Oleksyn, J., Reich, P.B., 2001. Modelling respiration of vegetation: evidence for a general temperature-dependent Q10. Global Change Biol. 7, 223-230.

Vitousek, P.M., Howarth, R.W., 1991. Nitrogen limitation on land and in the sea: how can it occur? Biogeochemistry 13, 87-115.

Wang, C.H., Wan, S.Q., Xing, X.R., Zhang, L., Han, X.G., 2006. Temperature and soil moisture interactively affected soil net $\mathrm{N}$ mineralization in temperate grassland in Northern China. Soil Biol. Biochem. 38, 1101-1110.

Wang, X.G., Zhu, B., Wang, Y.Q., Zheng, X.H., 2007. Soil respiration and its sensitivity to temperature under different land use conditions. Acta Ecologica Sin. 27, 1960-1968.

Wang, Q., Wang, D., Wen, X.F., Yu, G.R., He, N.P., Wang, R.F., 2014. Differences in SOM decomposition and temperature sensitivity among soil aggregate size classes in temperate grasslands. PLoS One 10 (2), e0117033. doi:http://dx.doi.org/10.1371/ journal.pone.0117033.

Weedon, J.T., Aerts, R., Kowalchuk, G.A., van Logtestijn, R., Andringa, D., van Bodegom, P.M., 2013. Temperature sensitivity of peatland C and N cycling: Does substrate supply play a role? Soil Biol. Biochem. 61, 109-120.

Wetterstedt, J.A.M., Persson, T., Agren, G.I., 2010. Temperature sensitivity and substrate quality in soil organic matter decomposition: results of an incubation study with three substrates. Global Change Biol. 16, 1806-1819.

Yang, L.L., Zhang, F.S., Mao, R.Z., Ju, X.T., Cai, X.B., Lu, Y.H., 2008. Conversion of natural ecosystems to cropland increases the soil net nitrogen mineralization and nitrification in Tibet. Pedosphere 18, 699-706.

Zhang, S.H., Chen, D.D., Sun, D.S., Wang, X.T., Smith, J.L., Du, G.Z., 2012. Impacts of altitude and position on the rates of soil nitrogen mineralization and nitrification in alpine meadows on the eastern Qinghai-Tibetan Plateau, China. Biol. Fert. Soils 48, 393-400.

Zheng, Z.M., Yu, G.R., Fu, Y.L., Wang, Y.S., Sun, X.M., Wang, Y.H., 2009. Temperature sensitivity of soil respiration is affected by prevailing climatic conditions and soil organic carbon content: a trans-China based case study. Soil Biol. Biochem. 41, 1531-1540. 